NBER WORKING PAPER SERIES

\title{
THE EUROPEAN UNION: A POLITICALLY INCORRECT VIEW
}

\author{
Alberto Alesina \\ Roberto Perotti \\ Working Paper 10342 \\ http://www.nber.org/papers/w10342 \\ NATIONAL BUREAU OF ECONOMIC RESEARCH \\ 1050 Massachusetts Avenue \\ Cambridge, MA 02138 \\ March 2004
}

We thank Ignazio Angeloni, Ludger Schucknecht, Guido Tabellini and especially Olivier Blanchard and Andrei Shleifer for useful comments. Alberto Alesina is grateful to the National Science Foundation for a grant through the NBER. The views expressed herein are those of the authors and not necessarily those of the National Bureau of Economic Research.

(C)2004 by Alberto Alesina and Roberto Perotti. All rights reserved. Short sections of text, not to exceed two paragraphs, may be quoted without explicit permission provided that full credit, including (C) notice, is given to the source. 
The European Union: A Politically Incorrect View

Alberto Alesina and Roberto Perotti

NBER Working Paper No. 10342

March 2004

JEL No. E0, H0

\title{
$\underline{\text { ABSTRACT }}$
}

In this paper, we present our view of the recent evolution of European integration. We first briefly describe the main features of the institution and decision making process in the European Union, with particular attention to the debate between federalists and super nationalists. We then identify two key issues in the process of European integration: 1) an emphasis on "institutional balance" based on a complex web of institutions with overlapping jurisdiction; 2) A conflict between a dirigiste versus a more laissez faire approach to government. We argue that the first problem leads to a lack of clarity in the allocation of powers between European institutions, confusion in the allocation of prerogatives between national governments and EU institutions, and lack of transparency and accountability. This dirigiste culture produces verbose rhetoric, which moves the European policy debate in the wrong direction.

We then study how these problems play out in four important areas: employment policies, culture and scientific research, foreign and defense policies, and fiscal policy. Finally, we study the implications of the recently proposed European Constitution as a potential solution of these two problems.

\author{
Alberto Alesina \\ Department of Economics \\ Harvard University \\ Cambridge, MA 02138 \\ and NBER \\ aalesina@harvard.edu \\ Roberto Perotti \\ Universita Bocconi, IGIER \\ Via Salasco 5 \\ 20136 Milano, Italy \\ roberto.perotti@uni-bocconi.it
}




\section{INTRODUCTION}

What is happening in Europe? Is Europe building a federal state similar to the United States, the "United States of Europe"? The answer is no. As article 1 of the recent draft Constitution states, Europe is a union of independent countries. Nevertheless an unresolved tension between those who would like the European Union to evolve into a super national entity (the federalists or super nationalists) and those who would like it to stay a union of independent governments (the intergovernmentalists) has shaped much of the history of European institutions.

The natural starting point for a US scholar studying the process of European integration would be the notion of "division of powers". Europe has developed instead a system of "institutional balance" based on overlapping jurisdictions: the legislative, executive, and regulatory powers are shared by many institutions, so much so that the distinction itself between legislative and executive acts is blurred - something that would make James Madison turn in his grave.

It could hardly be otherwise. The European Union has been created gradually by a group of established countries with different secular histories, including dozens of internecine wars, and different institutions. Understandably the European countries were wary that a single European institution would absorb too much of their own sovereignty; hence the emphasis on balance. But institutional balance and overlapping jurisdictions also lead to turf wars between institution, to confusion between the powers of member countries and of the European institutions, and to lack of transparency. This is the first key problem we identify.

The second important aspect of the process of European integration is a clash of different views of government, between a dirigiste attitude more common in Southern Europe and parts of continental Europe, and an Anglo Saxon, more laissez fair attitude. When the dirigiste attitude is kept in check, the result is not only policy inaction but also the production of verbose rhetoric of social engineering.

The welcome process of "institutional clarification," set in motion by the Constitutional Convention is trying to address the first problem. However one should not put too much faith into institutional design alone. The key issue is whether the European government will be based on the dirigiste approach or on a more Anglo Saxon laissez-fair one, perhaps with an added German sensitivity for federal systems. Consider this:: two key players in Europe, France and Britain, are on the same side of the federalist/intergovernmentalists debate, i.e. they are both intergovernmentalists; however, a hypothetical Europe with France at the driving seat would look quite different than one with a UK driver, regardless of the structure of institutions.

This paper is organized as follows. In Section 2 we describe the basic functioning of the current EU institutions. In Section 3 we discuss the two problems mentioned above. Section 4 illustrates the nature of these problems with some especially interesting examples. Section 5 studies how the Draft Constitution would affect the two problems.. The last section concludes.

\section{CURRENT InStitutions AND DECISION MAKING IN THE EUROPEAN UNION}

The European Council of December 2001 in Laeken set up a Convention with the task of integrating the treaties that regulate the functioning of the EU; this mandate evolved into the preparation of a draft Constitution. The Convention started its work in February 2001 
and delivered a draft Constitution in June 2003. This draft was to be examined and possibly amended in an intergovernmental conference, started in October 2003; the text approved by the intergovernmental conference was then to be ratified by all the 25 members of the European Union. However, negotiations over the draft Constitution broke down in midDecember 2003 over the reform of the system of allocation of voting rights. At the time of writing (end of January 2004) we still do not know what will happen, hence we present a picture of the EU institutions as they are now.

With heartfelt apologies, we need to start with some Euro-jargon, which is indispensable to understand the peculiar institutions of the EU. The EU is an umbrella organization that comprises three parts, or "three pillars." The first pillar is the European Communities (EC), consisting of the three communities established in the fifties and sixties. ${ }^{1}$ At the heart of this pillar are the "four freedoms of movement": of persons, goods, capital, and services, plus single market and competition issues; this pillar also covers a number of other issues, including agriculture, competition, and trade, and recently also visa and asylum policies. The other two pillars are part of the EU, but not of the EC. The second pillar includes the Common Security and Foreign Policy (CSFP). The third pillar, Justice and Home Affairs, now includes mostly police and judicial cooperation in criminal matters.

There is a fundamental difference between the first pillar and the other two. The EU institutions can make legislation which is directly applicable and has primacy over individual members' law for first pillar issues. In contrast, any decision concerning the two other pillars requires unanimity, and must be approved by national Parliaments to become applicable in member states.

We now turn to a brief description of the main roles of each EU institution. In so doing, we will use the following abbreviations: "Council" for "Council of the European Union"; "Commission" for "The Commission of the European Union"; "EP" for "European Parliament"; and "DC" for "Draft Constitution"; "QMV" for "Qualified Majority Voting".

\subsection{The European COUNCIL}

The European Council, which should not be confused with the Council of the European Union to be introduced below, is the forum where the heads of state of the European Union and the President of the Commission meet to discuss general issues. It has no formal decision-making power, yet it is the most influential body: it is here that all the major policy guidelines are set and that all decisions on the big issues are taken. The European Council meets at least every 6 months and it takes all decisions unanimously. Its presidency rotates every six months between all the EU members.

\subsection{The Council of The EURopean UNiON}

This body has both executive authority, which it has in large part delegated to the Commission, and legislative authority. All regulations and directives (the two most important legislative acts of the EC) must be approved by the Council, either jointly with the EP or after consultation with it.

The Council is composed of one representative per country, usually the national minister in charge of the issue under discussion. Hence, although it is a single institution, the

${ }^{1}$ The three communities of the European Communities are the ECSC (European Community of Steel and Coal, 1952; the EAEC (European Atomic Energy Community), 1958; and the European Economic Community, later European Community, 1958. The two latter communities were created by the Treaty of Rome of 1958. 
Council has several incarnations. One of the most visible is ECOFIN, the meeting of the finance ministers to discuss, monitor and coordinate budgetary matters. In total, the Council meets between 80 and 90 times in a typical year. The Council decides by unanimity in the most sensitive areas (including some first pillar issues), and in most cases by Qualified Majority Voting. The current QMV procedure assigns a certain number of votes to member countries as a function of their population size, but weighted in a way that favors small countries relative to strict proportionality.

\subsection{THE EUROPEAN COMMISSION}

The Commission has several roles. Among the most important are:

1) Right to initiate legislation: The Council and the EP cannot approve any piece of legislation if it has not been proposed by the Commission.

2) Executive power: The Commission monitors the implementation of the main legislation adopted by the EU.

3) Regulatory power: Mostly in the area of public undertakings and public service undertaking.

4) Power of surveillance of European law: The Commission is the "Guardian of the Treaty": if it detects infringements to the Treaties, after some attempts at resolving them it refers the matter to the European Court of Justice.

5) "Watchdog of the EMU": The Commission monitors compliance with the economic policies agreed on at the beginning of each year, and recommends various types of actions to the Council in case of non-compliance.

The Commission and its President are first nominated and then appointed by member countries after approval by the EP. Currently, each country has 1 commissioner, except that the 5 largest countries have 2 , for a total of 20 commissioners.

A common view is that the Commission is an unelected, unaccountable body, the quintessential technocratic institution. This picture is only partially correct. The Commission is accountable collectively to the EP: if the latter passes a motion of censure, the Commission must resign en bloc. Commissioners are not individually politically accountable to the EP, but the president of the Commission can dismiss a commissioner, if a majority of the commissioners agrees.

The Commission was designed initially as a European "think-tank", whose role was precisely to propose legislation to the bodies with true legislative power (see Devuyst (2003)). As a think-tank, its independence was paramount, and the lack of accountability a plus. But as the process of European integration progressed incrementally, the Commission was entrusted with more and more tasks, including an important executive power. This complicated the picture: independence and lack of accountability are appropriate for a think tank, not for an executive body. As we shall see, these multiple roles of the Commission are at the heart of much of the debate on institutional reform.

\subsection{The European Parliament}

The EP is directly elected in all EU member countries for 5 years and shares the legislative and budgetary authority with the Council. The Council's opinion prevails in matters of "compulsory spending" (mostly agriculture), while the EP's position prevails on the other matters - yet another example of the system of institutional balance. The EP is not currently regarded as a particularly important body. 


\subsection{The European COURT OF Justice}

The EU Court of Justice can "interpret" EU laws and seek its application. Court cases can be initiated both by governments and private citizens. Contrary to the American practice, its judicial rulings do not have legal stature in the EU. Still, the Court of Justice has acquired a considerable status within the EU bodies; for instance, its involvement in competition policy has been widely publicized.

\subsection{DECISION-MAKING IN THE EU}

There are two sources of legislation in the EU. The Treaties are the "primary" source: they need to be ratified by all members' governments. There are three main types of binding "secondary" legislation: regulations, directives, and decisions. ${ }^{2}$ There are basically two procedures to pass major legislation (regulations and directives) regarding the first pillar: consultation and co-decision; a third procedure, cooperation, is intermediate between the two and is being abolished by the Convention. In all cases, the Commission has the right of initiative.

Consultation applies to the most sensitive first pillar issues: Common Agricultural Policy, competition, taxation, guidelines for employment policies, industrial policy. The power of the EP is limited to a consultative role, and unanimity is required in all issues except agriculture and competition policy.

Co-decision applies to the remaining first pillar issues; it covers about 80 percent of the main legislative decisions, in particular all the issues decided by QMV, except agriculture and competition policy.

The co-decision procedure was introduced by the Maastricht Treaty in 1993 to enhance the role of the EP. The Commission's proposal must be accepted by both the EP (by majority voting) and by the Council (by QMV, but unanimity is required in culture, social security, and freedom of movement). If the Commission's proposal is amended, an extremely convoluted process is set in motion. Baldwin and Wagdren (2003) examine it and conclude that it is impossible to even establish who has agenda setting power in this process.

\subsection{SUMMARY}

The construction of the EU is the result of a delicate balance between two types of institutions and decision making methods: intergovernmental institutions, like the European Council and the Council of Ministers, that provide a forum for each country's demand, and super national institutions, like the Commission, the EP, and the Court of Justice, whose mandate and authority transcend the individual countries.

This dichotomy runs parallel to that between Community and intergovernmental methods, and between small and large countries. Usually, small countries see the Council and the European Council as dominated by the large countries; hence they tend to be staunch supporters of the Commission.

The distinction also parallels closely that between first pillar on one hand and second and third pillars on the other, and that between QMV and unanimity. Super nationalists typically would like to extend the areas covered by the Community method and by QMV, at the expense of unanimity. However, we believe that the juxtaposition QMV - unanimity is overstated: in reality, the major countries can always exercise a veto power in matters of importance, and small countries have no veto power even under unanimity, even though they

${ }^{2}$ A regulation refers to all member countries, and is directly applicable. A directive is binding on the objective, but leaves freedom to national legislation as to how to achieve these objectives. A decision applies to specific individuals, firms or countries; it is binding and directly applicable to whomever is addressed. 
may extort some rents by holding up a vote. Note also that the Luxembourg compromise looms large on the Council' $\mathrm{s}$ decision making process: ${ }^{3}$ by this informal agreement, if QMV applies and a country invokes its vital interests, the Council should try "within a reasonable time to reach solutions which can be adopted by all Members of the Council while respecting their mutual interests and those of the Community". "Thus, de facto all that the QMV does is eliminating the veto power of small countries, which in any case are extremely unlikely to exercise it, but it does not change the interactions between the largest countries. An example is agricultural policy: although formally not subject to unanimity, no major decision would be taken without the consensus of France and Germany.

\section{Problems}

We now illustrate the two problems we have identified:

\section{Problem 1: Institutional balance based on a complex web of institutions with overlapping jurisdiction.}

\section{Problem 2: A conflict between a dirigiste versus a more laissez faire approach to government.}

\subsection{PROBLEM 1: OVERLAPPING JURISDICTIONS}

Problem 1.A: Lack of clarity in the allocation of powers

The structure of decision-making at the European level leads to confusion about the allocation of powers between the Commission (the supernational body par excellence) and the Council (the quintessential intergovernmental body), and about the role and structure of the European Council. One may argue that a system of overlapping jurisdictions can still work well if accompanied by a smooth system of checks and balances, as it is arguably the case in the US. . We will argue instead that in Europe the confusion of roles has not been resolved successfully.

Problem 1.B: The allocation of prerogatives between national governments and EU institutions.

One consequence of the confusion about institutional prerogatives is that EU institutions have encroached into national competencies. Obviously part of the "secular" increase in the power of EU institutions has been by design and approved by all member countries. But there is more than that. The theoretical literature on federalism provides a clear principle for the allocation of responsibilities between national governments and the EU: the latter should engage in those policy areas where economies of scale and externalities are large, and heterogeneity of preferences amongst different countries are low.

This principle has not been applied coherently. The EU governing bodies are increasingly involved in a variety of areas where it would not be unreasonable to argue that

\footnotetext{
${ }^{3}$ In 1965, France blocked the working of the EC by practicing a policy of empty chair for six months, because it believed that the common agricultural policy was going in a direction that would badly damage its farmers. The impasse was resolved by the Luxembourg compromise, which is an informal agreement and not part of any Treaty or law.

${ }^{4}$ Even this agreement is not uncontroversial: France interpreted it as stating that unanimity would be applied when it is invoked.
} 
economies of scale or externalities are virtually non-existent, while divergence of preference is large. For example Nugent (2000), Alesina and Wacziarg (1998), Berglof et al (2003), and Alesina, Angeloni and Schucknecht (2002) document the large increase of EU legislation in areas such as welfare and citizen protection, that are quite far from the original mandate of EU institutions.

\section{Problem 1.C: Lack of transparency and accountability.}

The principle of institutional balance, and the ensuing convoluted nature of EU governing institutions described above, make them prone to accusations of "lack of legitimacy", "democratic deficit", and "lack of accountability".. According to the latest data from Eurobarometer, 74 per cent of EU citizens list as a priority for the EU "getting closer to the European citizens, by informing them more about the EU".

We believe that under the current institutional balance approach there is no solution to the legitimacy and accountability problem. Implicitly or explicitly, the source of legitimacy for EU institutions is taken to be the EP, on the ground that it alone represents the will of the European people directly. But it is very unlikely that in the short and medium run the European citizen will view the EP as their true representative.

In addition, it is not totally clear, even in theory, how much different bodies should be accountable, and this confusion stems from the multiple roles played by the same body. Take the Commission, for instance. If one focuses on its "think tank" role, one would want to make it as independent as possible from the EP: there is nothing wrong with a technocratic think tank - indeed, this is part of the definition itself of a think tank. But if one focuses on the executive role of the Commission, clearly accountability becomes an important issue. Depending on which side of the Commission one considers the most important - the executive, regulatory or legislative - more accountability, politicization and legitimacy can be good or bad. ${ }^{5}$

\subsection{Problem 2: Dirigisme AND RHETORIC}

The second problem is the clash of cultures between dirigisme and laissez faire, and the resulting widespread rhetoric. Although the divide between intergovernmentalists and super nationalists has attracted most of the attention, we believe a second crucial divide is that between two very different visions of policymaking, which will confront each other in any given institutional setting. A dirigiste and regulatory approach to the economy, with a heavy emphasis on coordination, intervention and quantitative targets, is still very pervasive. This emphasis on "coordination" and "plans," has had (so far!) a relatively limited impact because the power of EU institutions in many policy areas are indeed limited yet. But precisely because the scope for actual intervention is constrained, the result of this clash of cultures is often inaction and a pompous rhetoric.

Two questions come to mind:, why is the rhetoric dirigiste and not laissez faire? And why should we worry about it?

On the first question the answer is two fold. One has deep cultural roots: the pragmatism of the Anglo Saxon culture versus the tendency to verbosity of Latin cultures. However, we are no experts in cultural history, so we leave it at that. The second reason is that it is natural to have more to say if one believes in social engineering, coordination, public goals, market regulation than if one simply wants to let markets take their undisturbed

\footnotetext{
${ }^{5}$ For a recent formal discussion of electoral accountability versus "experts" see Dewatripont Jewitt and Tirole (1999a,b) and Alesina and Tabellini (2003).
} 
course. A dirigiste frustrated by inaction is more likely to produce numerous white papers describing his plans for a dream world.

The second question is more important. One view is that this rhetoric is irrelevant or even useful because it allows well intentioned policymakers to "work" while dirigiste bureaucrats are busy writing irrelevant white papers. We find this view naïve. An empty rhetoric can become a justification for heavy and misplaced interventionist governments, and it can mislead the public debate, generating unreasonable expectations in the public, thus creating obstacles for well intentioned policymakers facing tough choices.

\section{THE WORKINGS OF EU INSTITUTIONS}

We now turn to a discussion of several examples of policy areas that illustrate the problems we discussed above.

\subsection{EMPLOYMENT POLICIES}

In December 1991, all member countries except the UK agreed to a Charter of Fundamental Social Rights, which was later ratified by the new UK Labor government. It became a new chapter in the Amsterdam Treaty of 1997, making the enforcement of its rights a priority of the Union's economic policy. In fact, based on this background, the Luxembourg Job Summit of 1997 launched the European Employment Strategy, with a series of indications on a wide-ranging set of topics, from vocational training to improving the social dialogue. The European Council of March 2000 in Lisbon (a meeting that has since reached quasi-mythical status in Europe) set up a series of criteria and policy suggestions to reach "a new strategic goal for the next decade: to become the most competitive and dynamic knowledge-based economy in the world, capable of sustainable economic growth with more and better jobs and greater economic cohesion". It is interesting to read the targets for 2010 envisioned by the Lisbon strategy:

\section{Box 1: The ideal "knowledge-based society"}

- Employment rate: Overall 67\% (2005), 70\%; Women 57\% (2005), 60\%; older workers $50 \%$

- Long Term Unemployment prevention: Every young and adult unemployed to be offered a new start before 6 or 12 months respectively

- Proportion of unemployed participating in active measures $20 \%$

- Increase of effective average exit age: by 5 years

- Reduction of school drop out rate: $10 \%$ at EU- level and half 2000 percentage in each Member State

- Raising educational attainments of 25-64 years olds: 80 percent

- Participation of adults in education and training: 15 percent at EU-level and no Member State below 10 percent

- Coverage of childcare services 0-3: 33 percent

- Coverage of childcare services 3-6: 90 percent 
To achieve these targets, the European Council introduced the new method of open cooperation, which was essentially designed to allow some form of coordination based on peer pressure in the absence of legal instruments in virtually all the areas touched by the document. It consisted of a complicated system of coordination and monitoring of employment policies. Each year, the Council issues the Employment Guidelines, plus the Council Recommendations to the Member States on Employment Policies, in turn based on a Commission recommendation. The national countries then submit a National Action Plan on employment policies, which reports on the steps taken to implement the Employment Guidelines. The Council then issues the Joint Employment Report, with a detailed assessment of how the Member States responded to the recommendations of the Employment Guidelines.

One can disagree on what is the appropriate level of coordination of labor market policies, but it is interesting to note three features of this strategy:. First, the insistence on setting numerical targets (a practice reminiscent of the discredited industrial plans of the sixties), moreover undifferentiated among EU countries. Second, the prescription of highly controversial policies as self-evident "goods": for instance, evaluations of training programs have raised doubts on their cost-effectiveness, except in a few specific cases; yet there is no mention of this. Third, the rhetoric: from the high-sounding declarations on the "knowledgebased society", to a myriads of meaningless pompous statements. ${ }^{6}$

One could think that this flurry of activities around the buzzword of "knowledgebased society" set in motion by the Lisbon process is largely an innocuous exercise in Euroverbosity. Still, we believe this exercise is not just a questionable use of time and money. No government today takes the guidelines on employment policies as an even remotely binding constraint; and we know of no country where the National Action Plans have any role in guiding policy. Governments seem to participate because, after all the enthusiasm and the media attention on the "Lisbon process", they are caught in a bad Nash equilibrium in which a withdrawal would qualify them as Euro-villains. Yet this Kafkian exercise has contributed to set back the level of the debate and of understanding by the public by giving the impression that some EU institution actually knows how to solve the problem of European unemployment, if only national governments cooperated....

Problem 2, (dirigiste rhetoric) is truly rampant here: inability to act (as yet!) is substituted by pompous verbosity.

\subsection{Cultural POlicy}

The EU funds research in Europe mostly through its Framework Programmes, of which the latest one, the $6^{\text {th }}$, was launched in 2003. Its budget is $€ 17.5$ bn over a period of five years, or about 4 percent of the EU budget. The Framework Programme is adopted by a co-decision of the Council and the EP, based on a recommendation by the Commission; the co-decision sets out the "Thematic priorities" for all projects that want to be considered for funding. In the $6^{\text {th }}$ Framework Programme, there were 7 thematic priorities, for each of which the Council decision details a list of research priorities. The last thematic priority, "Citizens and governance in a knowledge based society", covers social sciences: it has a budget of only about $€ 200 \mathrm{mn}$. Despite its limited size, it is instructive to read some of its research priorities, as laid out by the Council:

\section{Box 2: What European social scientists should be doing}

\footnotetext{
${ }^{6}$ For instance, from the Commission recommendation for the Council recommendation on the Italian employment policies of 2002: "[Italy should take] measures to increase labor market flexibility and modernize work organization, while promoting the synergy between flexibility and security and avoiding marginalization of disadvantaged persons". Beautifully said.
} 


\section{according to the European Union}

(i) Knowledge-based society and social cohesion

The building of a European knowledge society is a clear political objective for the European Community. The research aims to provide the basis of understanding needed to ensure this takes place in a manner which accords with specific European conditions and aspirations.

- Improving the generation, distribution and use of knowledge and its impact on economic and social development [....] Research will focus on: characteristics of knowledge and its functioning in relation to the economy and society, as well as for innovation and for entrepreneurial activities; and the transformation of economic and social institutions; the dynamics of knowledge production, distribution and use, role of knowledge codification and impact of ICTs; the importance of territorial structures and social networks in these processes.

- Options and choices for the development of a knowledge-based society [....] Research will focus on: features of a knowledge based society in line with European social models and the need to improve the quality of life; social and territorial cohesion [...]

- The variety of paths towards a knowledge society. [....] Research will focus on: globalization in relation to pressures for convergence; the implications for regional variation; challenges to European societies from a diversity of cultures and increased sources of knowledge [...](ii) Citizenship, democracy and new forms of governance

The work will identify the main factors influencing changes in governance and citizenship, in particular in the context of increased integration and globalization and from the perspectives of history and cultural heritage [...]Research will focus on: relationships between integration, enlargement and institutional change within the context of their historical evolution and with a comparative perspective [...]

The research activities carried out within this thematic priority area will include exploratory research at the leading edge of knowledge on subjects closely related to one or more topics within it. Two complementary approaches will be utilized: one receptive and open-the other proactive.

These directives to European researchers are cast in sufficiently loose and meaningless (what are the "receptive" and the "proactive" approaches to research?) terms that they may well turn out to be harmless. Still, they denote a vision of "research policy" grossly at odd with the model we believe is prevalent in most Anglo-Saxon countries: this includes a notion of scientific innovation as, almost by definition, unpredictable; and a role of public funding of research as encouraging innovation rather than imposing straightjackets on what is admissible research.

Once again this is an illustration of Problem 2 above.

\subsection{FOREIGN AND DEFENSE POLICIES}

\section{A. A brief history of European foreign policy.....}

Foreign and defense policies are areas with obvious economies of scale. The European countries started to talk seriously about foreign policy questions in the context of European institutions in the early seventies. After a few false starts the Hague summit of 1969 created the "European Political Cooperation" which established regular meetings of foreign ministers and diplomats to discuss issues of foreign policy and exchange 
information. ${ }^{7}$ The result of this effort was unimpressive: Gordon (1997) notes that the outcomes of the EPC were "mostly declaratory, always based on consensus and limited to uncontroversial or peripheral issues".

The next big step was the Maastricht Treaty of 1991-92 that created a Common Security and Foreign Policy (CSFP). Despite some lip service to the Commission involvement in the CSFP, it was clear from the very beginning that this branch of policymaking was solidly in the hands of member countries national governments. Between 1994 and 1997 the EU adopted 66 common positions on just about any foreign policy issue and the CFSP issued a flurry of declarations, 163 only in 1998: Chris Patten, the current commissioner for External Relations, dryly noted that "they came usually a week or two after they could influence events" .

But EU foreign policy failed miserably its first true test: Yugoslavia. Richard Holbrooke (1999), the Clinton envoy negotiator in Yugoslavia, reveals the failure of the Europeans diplomacy facing a home turf problem. The cause was twofold. First, the lack of common purpose of European policy. Germany was traditionally closer to the Croats (their ally in the Second World War) and France and Britain to the Serb (their ally). Second, the reluctance of Europeans to use force. In one of the most famous episodes, unarmed Dutch peace keepers (although it is far from clear exactly what peace they were trying to keep) watched helplessly truckloads of Muslim civilians taken to their deaths by the Bosnian Serb paramilitary forces in Srebrenica. According to Red Cross records, in the five days period July 12 to 161995 the eventual death toll of civilians in Srebrenica was 7,079. In fact, the Dutch peace keepers were even taken prisoners, becoming an obstacle to further action to prevent atrocities: while the massacre was taking place "the Dutch government refused to allow air strikes until all its soldiers were out of Bosnia.... The other Europeans had reached their limits; with their soldiers also at risk they were not going to engage in any action that endangered the Dutch" The Americans had a very hard time extracting from their allies a "go ahead" for the bombing; in the end they took the initiative unilaterally.

Partly as a response to this failure, the Treaty of Amsterdam created a "High Representative for the CFSP," with the purpose of forging and carrying out a common position on foreign policy. This position has been filled since its creation by the former Spanish foreign minister Javier Solana. It has become something of a cliché in Europe to mention this position and the word "success" in a single breath. This obviously depends on one's standards. It was widely reported that during the most serious test of the European foreign policy after the Balkan crisis, the Iraq crisis, Javier Solana had serious problems even getting through to his counterpart Colin Powell. Obviously there was little point in talking to the exponent of a common foreign policy position that did not exist.

The one achievement of the position that is invariably mentioned is the reconstruction phase in the Balkans, where the differences between European countries had long been resolved by the American-led conflict itself. At the moment, this position coexists with the Commissioner for External Relations, with an ill-defined division of labor. Once again, this is a recipe for institutional turf war, which manifested itself clearly during the runup to the Iraqi conflict.

\section{B. ... and of European defense policy}

A strong and powerful foreign policy needs a strong military, and European countries are too small to achieve a credible military strength individually. But progress towards closer military cooperation and integration has always been hampered by two clearly contrasting views of this force: as complementary to NATO (Britain) or as substitute for or even rival to

\footnotetext{
${ }^{7}$ For more details on the EUP see Nutall (1992)

${ }^{8}$ A cited by Evert (2002).
} 
NATO (France, and possibly Germany). This, in turn, is closely linked to two alternative views about the common foreign policy.

With the fall of the Berlin Wall and the revival of the "stronger Europe" position, inevitably the relation between NATO and any European defense policy became the key issue. In 1991 in Maastricht the two views could not be reconciled and the compromise was a declaration that the Western European Union (created in 1948 as a first step towards closer military cooperation) was "the European pillar of the Atlantic Alliance" and "the defense arm of the EU", although the practical implications of this declaration were far from clear. In the same year, the Europeans created also a "European Security and Defense Policy (ESDP) within NATO.

The Europeans also realized that their first need would have been a Fast Response Force to be deployable in a short time in case of a crisis. The Helsinki Headline Goal was to create a force of 60,000 deployable in 60 days and to be maintained for at least a year. The Clinton's administration position towards the FRF and ESDI was summarized in the famous "3 D's": any European common defense policy should not duplicate NATO assets, should not discriminate against NATO members that are not part of the EU, and should not entail actions that would decouple Europe from the US.

The Bosnian crisis was also a watermark for the European defense policy: the Europeans realized that without NATO support they would have not been able to wage a campaign of military significance, hence the key problem switched from "how to exclude NATO" to "how to integrate into NATO". Hence, between 1994 and 1996 the NATO countries' agreed to the creation of combined joint task forces between NATO and the WEU; and by the Berlin agreement of 1996, the latter could use NATO assets for mission of the joint task force. The Clinton administration position was that allowing access to NATO assets would have prevented duplication of NATO military headquarters and military staff

However, the Berlin agreement quickly proved of little use. As Shacke (2002) argues, the European quickly realized that the key problem was not access to NATO assets, but access to US assets: if the US was not committed to a mission, having access to NATO assets without the US contribution would not allow putting together missions of military significance.

In fact, at the end of November 2003 France, Germany and the UK finally seemed to have come to an agreement on a common defense policy. Its core provisions were the possibility of military operations under the label of the EU, a move long resisted by the UK. However, no sooner was the deal announced that the usual variety of interpretations surfaced: the UK insisted that these EU operations would not undermine NATO's role as the primary military organization in Europe; France and Germany interpreted instead the deal as a first move towards independence from NATO.

\section{Is a European defense and foreign policy feasible?}

In our view, a CSFP will be impossible in Europe for many years to come, for essentially four reasons. First, the persistent divergence of preferences among European countries on goals and means in foreign policy. Those in favor of a common European foreign policy typically refer to the generally wide support amongst European citizens for a common foreign policy: according to the latest data from the Euro barometer about 70 per cent of European citizens feel that the EU should be more involved in foreign policy. ${ }^{9}$ But these polls do not say "which" foreign policy the citizens of different countries favor. In fact, the fault lines on foreign policy run very deep in Europe. It is easy for a US commentator to underestimate the extent to which the support for a common foreign policy is driven by cultural anti-Americanism in continental Europe. A recent survey sponsored by the European

\footnotetext{
${ }^{9}$ Eurobarometer, March May 2003.
} 
Commission has found that Europeans believe that the United States is second only to Israel and North Korea (in this order) as an enemy of world peace. Anti-Americanism is instead a minority position in Anglo-Saxon countries and in the former communist countries that will soon become members of the EU. It is difficult to think how these two divergent views of foreign policy could be reconciled in a common foreign policy.

Second, and yet again, the all-pervasive principle of institutional balance. Foreign policy in the US is clearly the domain of the executive, particularly during a crisis. For instance, once the executive has decided to go to war, there is very little Congress can do politically to stop the President. Even if all European countries decided to give up their sovereignty in issues of foreign policy - an unlikely event as we have seen - , different EU institutions would still want to have a say, and they are entitled to do so under the DC.

Third, unwillingness to spend on defense. The US defense budget is the largest in the world, and greater than the combined spending of the next 25 countries. Europe spends about 2 per cent of GDP in defense, the US about 3.5 and growing. But these numbers underestimate the differences in military capabilities on the two sides of the Atlantic. For most of the post war period the US spent much more than Europe on defense, building an enormous advantage in terms of stock. Some experts (Evert (2002)) argue that the difference in technological level of the US versus European armies is such that if Europe does not catch up quickly, the two militaries would not even be able to "communicate" properly. US spending is also geared towards more modern and lethal weapons: the US spends about $\$ 26,800$ in defense R\&D per soldier, as opposed to about $\$ 4,000$ in the EU. ${ }^{10}$

As a result of this investment in extraordinarily expensive technology, the US has a full control of the commons, i.e. the sea, the air and the space, as Posen (2003) documents. A single nuclear sub marine which is key for sea control costs between 1 and 2 billion dollars. The Marine Corps alone has more military personnel than the combined land and air forces of the United Kingdom. It is extremely unlikely that Europe can come even close to such powerful military given the already heavy burden of its public sector.

Fourth, the aversion of important EU members to engage in military actions and put men and women on the ground. As Posen (2003) notes one area in which the US is not as strong is in the size of its ground troops, so it becomes especially difficult for the US to engage an enemy in its own territory. Europe could in principle provide help in this dimension, but based on previous experiences in Yugoslavia it is unclear whether the European public opinion and European governments would tolerate loss of European lives. In addition, the result of the large investment in technology by the US is a great reduction of risk to military personnel. Hence, currently to achieve the same military objective EU forces face much larger risks than the US forces; as Schacke (2002) notes, this reinforces the unwillingness of European countries to put men and women on the ground - a catch-22 problem for Europe.

\section{Summing up}

The history and recent developments of foreign policy at the European level reflect in many ways the two problems above. First, Problems 1.A - the turf war between European institutions - and 1.B - the fuzzy allocation of powers between national governments and European institutions. Second, Problem 2, which manifests itself not so much in dirigisme, impossible given the disagreement between members, but in the verbosity that and still largely characterizes the debate on the issue.

${ }^{10}$ Schake (2002), citing John Dowdy of McKinsey in "Impotent Europe", the Wall Street Journal Europe, September 212001. 


\subsection{The MaAstricht Treaty and the Stability and Growth PaCt}

A. What is (or was) it?

The Maastricht Treaty, in effect since 1993, established that EU members wishing to qualify for EMU (the European Monetary Union) had to show sufficient budget discipline by 1998. Specifically, by that date the budget deficit and government debt had to be below 3 and 60 percent of GDP, respectively. The same limits applied to EMU members even after $1998 ;{ }^{11}$ however, "exceptional and temporary" deviations from the 3 percent deficit limit were allowed. De facto, the debt requirement was never enforced; hence we will focus on the deficit criterion. The Stability and Growth Pact of 1997 (effective from January $1^{\text {st }} 1999$ ) was then designed to give concrete content to several aspects of the Maastricht Treaty regarding economic policies in the EMU. A recent vote of the Council in November 2003 suspended the application of the Pact to France and Germany despite their open violation of it; thus, at the time of this writing the Pact may be declared officially dead soon. Still, it is instructive for our purpose to revisit its birth, life, and death.

Let's begin with what the Pact is. It first introduces the notion of "appropriate medium-term budgetary objective of positions close to balance or in surplus" that each EMU country should follow, although it quickly became clear that there was no agreement on the interpretation of this notion. The Pact then tries to give operational content to the notion of "exceptional and temporary" deviation of the deficit from its 3 percent limit. This can result from a recession of at least 2 percent of GDP; however, a country can also argue that a smaller recession constitutes a justifiable cause, although member countries were asked to commit not to make such a case if GDP falls by less than .75 percent.

The Treaty and the Pact also put in place a system of multilateral surveillance similar to that for the Lisbon process ${ }^{12}$. Each year, acting on a recommendation by the Commission, the Council adopts the Broad Economic Policy Guidelines; each EMU member submits a Stability Programme with its medium terms objectives for the budgetary position; and again on a recommendation by the Commission, the Council then delivers an opinion on each Stability Programme. In case of actual or expected violations, an Excessive Deficit Procedure is started; this long process can lead to a series of recommendations and warnings of increasing severity, until refundable, non-interest bearing deposits of up to .5 percent of GDP can be imposed in case of repeated non compliance.

\section{B. Why was it adopted?}

Economists have long tried to find an economic rationale for the budget deficit provisions of the Maastricht Treaty and of the SGP, with little success. In fact the motivation for the MT and the SGP was largely political. Germany was about to surrender control of its currency, and feared that this would endanger its long-cherished monetary stability. As a consequence, it wanted to make sure that it would not have to share membership of the EMU with countries whose economic policy was, in some sense, grossly mismanaged. The budget deficit and government debt were the two best observable proxies for the somewhat hard to define notion of economic mismanagement.

${ }^{11}$ They also apply to EU members that are not EMU members (Denmark, Sweden, and the United Kingdom): however, for these countries there are no sanctions in case of violations of these rules.

${ }^{12}$ In fact, it has been decided recently that the Employment Guidelines and the Broad Economic Policy Guidelines would be "coordinated". 


\section{How has it worked?}

The run up to the monetary union has coincided with a sharp reduction of European deficits. For some countries (especially Italy and Greece) the threat of exclusion from the initial phase of the monetary union acted as a critical incentive; but during the nineties the world business cycle was also favorable, making it easier to achieve fiscal virtue.. As the pressure to converge to the Euro vanished and the world economy turned sour, maintaining the Pact has proven challenging. The Pact came under attack from several political and academic quarters on two grounds. First, the Pact prevents countries from using fiscal policy for anti cyclical purposes, exactly when they need the fiscal instrument the most, namely when they have given up the monetary instrument. Second, the Pact has forced cuts on growth enhancing public investment. Gali and Perotti (2003) show that both criticisms do not stand up to careful scrutiny.

\section{An evaluation.}

The biggest problem with the implementation of the Maastricht Treaty and the Pact is that they have opened the door for an expansion of the powers of the Commission far beyond those initially envisioned; and that these enhanced powers almost invariably express themselves as an attempt at coordinating and fine tuning the fiscal policy of member to an extent that is clearly beyond the expertise and capabilities of any institution.

The best, and admittedly extreme, illustration of this is the highly publicized reprimand to Ireland. In 2001, Ireland was coming from a decade of unprecedented growth (in fact, the highest growth rate in the world, with the possible exception of China), coupled with the highest budget surplus and the lowest public debt burden in the Euro zone. Starting from a surplus of 4.5 percent of GDP, in its Stability Programme of 2001 the Irish government proposed a reduction in the cyclically adjusted surplus by .3 percentage points in 2001, and by a negligible amount in 2002. This was to be achieved mostly by reducing income and indirect taxes and by slightly increasing government investment, a reversal of the indications in the Stability Programme of a year earlier. The ECOFIN Council of February 2001 issued an unprecedented reprimand to Ireland with the following motivation: ".... the Council considers that the stimulatory nature of the budget for 2001 poses a considerable risk to the benign outlook in terms of growth and inflation.... [...] the strategy of inducing labor force increases though an alleviation of the direct tax burden, which was recommended in the 2000 Broad Economic Policy Guidelines ... may have become less effective than in the past, because it took place in the context of an expansionary budgetary policy... Further, while indirect taxes cuts have a once-and-for-all effect on the price level, they probably have no lasting effect on the rate of inflation but clearly further stimulate demand" (Official Journal C 077, 9.3.2001, p.7).

To be fair, nothing serious has happened after this incident, which however kept Irish and European officials frantically busy for weeks; yet, this example illustrates what is wrong with the implementation of the Pact, and more generally with much of the dirigiste culture of the institutions involved with economic policy. In particular, a seemingly unlimited confidence in their ability to determine the quantitative consequences of infinitesimal changes in this or that type of expenditure or tax. Notice also in the passage above the rather exotic statement about the cross derivatives of inflation to taxes and change in the budget deficit, and other statements inconsistent with each other.

A second manifestation of the attempt at economic dirigisme is in the insistence on coordination of member states' economic policies, as illustrated in a recent proposal for an overhaul of the European Union by the Commission: "Policy co-ordination should make it possible to attain a common assessment of the economic situation, agree on the orientation of the policy response and monitor its implementation. It should be regular, not limited to 
exceptional circumstances.... The instruments of economic policy coordination, particularly the major economic policy guidelines and the opinions on the stability and convergence programmes should be drafted on the basis of proposals from the Commission rather than mere recommendations from which the Council may depart by qualified majority." (European Commission (2002), p.7, emphasis in the original). .

\section{E. The (near) death of the Pact}

On November 25 of 2003 the Council met to decide on the cases of France and Germany, which had been clearly breaking the 3 percent limit for some time. It was a clear cut case of violation, much more serious than Ireland. The Council rejected the recommendations by the Commission that these two countries should implement urgent measures to reduce the cyclically adjusted deficit by .4 and .8 percentage points of GDP, respectively. Instead, with a decision of doubtful legal basis, it voted to "hold the Excessive Deficit Procedure in abeyance" for these two countries. This unprecedented and very visible decision to a large extent killed the Pact and lead to a very harsh exchange of accusations between Commission and Council: in fact, at the time of writing (end of January 2004) the Commission is suing the Council at the European Court of Justice over the issue. Clearly, there is no chance that the Pact can be applied in the future to any country after it was so overtly suspended in the case of the two largest countries of the Union. This event has proven that, whatever sovereignty large countries are willing to cede to the Commission in matters of importance like fiscal policy, they will take it back - legally or less legally if necessary for a sufficient number of them. It is probably more constructive to simply recognize this point of realpolitik, declare the Pact dead, and return fiscal discretion to the national governments. The heavy involvement of the Commission in the minute fiscal decisions of member countries is unwarranted, confusing and counterproductive.

The Commission could still have an important role, but one that is more reminiscent of its original role as think tank of EU institutions: it would require national governments to be as explicit as possible about what they are doing in fiscal matters, it could act as a watchdog that flags creative accounting (broadly defined to include unreasonable projections), and that presents the likely scenarios on the basis of its own assessment of demographic and other trends etc. This task is important, because it would enforce a process that relies mostly on peer pressure and bad publicity to achieve whatever fiscal discipline the EU governments decide is desirable.

\section{F. Summing up}

The life and death of the Pact are illustrations of both Problems 1 and 2. We have seen the extraordinary amount of dirigiste rhetoric that has accompanied several parts of the life of the Pact. Its recent life is also an example of the fuzzy allocation of powers between European institutions - Problem 1.A - and between European institutions on one hand and member states on the other - Problem 1.B.

\section{SOLUTIONS?}

We now briefly describe how the draft Constitution would affect the problems we have illustrated above. This document - which is several hundred pages long - is divided in three parts. Part 1 describes the nature, competences and institutions of the union in general 
terms. Part 2 contains a list of fundamental rights. Part 3 contains a very long list of Protocols and Annexes regarding the functioning of the Union.

\subsection{Problem 1 and the Draft Constitution}

\section{Problem 1.A}

The rotating presidency is abolished, and a chairperson of the EU is chosen by the European Council for a period of two and one-half years. The new President will also represents the EU abroad "at a comparable level", hence in meetings with, say, the US President. In deference to the principle of institutional balance, the DC also envisions some marginal enhancement of the power of the Commission President.

In the area of the Common Security and Foreign Policy (CSFP) the DC creates a new position, the "EU minister of foreign affairs", which combines the positions of the High Representative for CSFP and of the Commissioner for External Relations. An agent of the Council, he will chair the meetings of foreign ministers and will be accountable to member states, not to the Commission. Still, and again in deference to the principle of institutional balance, the DC stipulates that "with the exception of CFSP.... [The Commission] shall exercise the Union's external representation". Combined with the important external role attributed to the new President of the EU, this tri-partite assignment of responsibilities for external relations again appears a recipe for turf wars.

Overall, these changes appear to strengthen the European Council at the expense of the Commission. As such, they are the result of a clear intergovernmental choice; in fact, they were supported by the five largest countries and by Denmark and Sweden, and opposed by all other countries and by the Commission..

But other changes might well go in the opposite direction. A provision with possibly important consequences is the change in the Qualified Majority Voting (QMV) procedure in the Council. In particular, the new QMV system envisioned by the DC greatly simplifies the procedure and de facto reduces the threshold of votes for a qualified majority.

Thus, although the flavor of the DC is certainly not favorable to the Commission, it is hard to predict whether, in practice, the Commission will gain or lose power relative to the other institutions. And perhaps we should not care too much. In our view, the balance of power within the EU is driven more by the political climate and the influence of the various countries and coalitions than by the institutional changes that are currently on the table. Consider the history of the Commission. In the seventies and eighties, the Commission played a key role as provider of the impetus for ever increasing integration. The importance of the Commission has decreased in the nineties, for several reasons. Undoubtedly, some Euro-fatigue set in, as many countries wanted to take a breather after decades of breathtaking integration; the Franco-German entente, that had provided the political backing for most Commission initiative, basically dissolved with German reunification, for political reasons but also for personal reasons (Schroeder and Chirac never managed to replicate the chemistry that bonded Kohl and Mitterrand); the Santer Commission was embroiled in accusations of corruption, and had to resign in 1999; its successor, the Prodi Commission, has been beset by leadership and image problems in many countries; and the Commission itself has ruffled many feathers, by continuing to claim powers in areas in which no major member state will relinquish to a super national institution.

\section{Problem 1.B}

One important goal of the DC should have been to clarify the division of responsibility between the EU and national governments and to limit the EU role. Indeed, in 
an effort to satisfy the intergovernmentalists, the DC now goes into lengthy discussions of the role of the EU versus national governments in all policy areas, with a rich array of distinctions between exclusive and shared competences. The DC lists five areas where the EU has exclusive competence: monetary policy, commercial policy, customs union, conservation of marine biological resources, certain international agreements. But the DC also lists 10 areas where the EU shares competence with Member States, including such broad and loosely defined areas as "economic, social and territorial cohesion", and "freedom, security and justice". Moreover, the DC gives a very generous interpretation of the notion of shared competence: "Member States shall exercise their [shared] competence to the extent that the Union has not exercised, or has decided to cease exercising, its competence" (art. 11). The DC also provides for an unspecified "supporting, coordinating or complementary action" in five more areas, including industry, culture, and education and vocational training (art. 16). Finally, the DC states rather cryptically that "the Union shall have competence to promote and coordinate the economic and employment policies of Member States" (art. 11). These provisions are unfortunate. A legitimate interpretation of all this language is that it intends to leave the door open for future more or less veiled extensions of competences on virtually all possible areas one can think of.

Part 3 of the DC, probably read in its entirety by very few courageous Europeans, (a group that does not include the authors of this paper), is essentially a collection of documents describing in minute details the functioning of the Union in all policy areas, from agriculture and fisheries to transportation, from judicial cooperation to humanitarian aid. This is probably the part of the Constitution that, because of its level of detail and sheer length, has raised the most eyebrows. Somewhat surprisingly, this was included largely at the insistence of conservative governments and parties, who thus wanted to make sure that the competences and, implicitly, the limits to the EU institutions were clearly enshrined at the constitutional level. ${ }^{13}$ However, this attempt largely failed: the ambiguous wording of Part 1 of the Constitution can be used to justify any de facto allocation of competences to EU institutions.

\section{Problem 1.C}

Here the DC has achieved some progress. It does away with the confusing partition of EC and EU. All Treaties and laws now fall under the heading of EU; and, importantly, the EU as a whole has now a separate legal personality. In principle, a legal personality means that, like pillar 1 legislative acts, pillar 2 and 3 legislative acts do not have to go through approval of each parliament to become national legislation. A legal personality also means that the EU can be represented as a separate legal entity in international forums. But since these decisions, and foreign policy, are subject to unanimity in most cases, the practical implication of this is as yet limited.

\subsection{Problem 2 and the Draft Constitution}

The DC has taken several steps back on this problem. It begins with an embarrassingly Eurocentric and historically inaccurate statement that "Europe has brought forth civilization". We thought that civilization (whatever that means) was born in Mesopotamia, Egypt or may be China.

After this rather inauspicious beginning, Part 2 contains 54 articles of fundamental rights, many of which include several related rights. We counted at least 91 separate rights in these 54 articles. We doubt that many of them would rise to the dignity of a "right" in most constitutionalists' views. A highly cited one is the right of access to free placement service.

${ }^{13}$ This view was expressed to us by a senior participant in the Convention. 
This is one of the 11 articles under the chapter of social solidarity, with many very specific welfare rights spelled out. On the other hand Article 17 stresses that "the use of property may be regulated ......for the general interest". One could go on but it is quite clear that Part 2 of the DC is deeply rooted in a Continental European tradition as opposed to an Anglo Saxon one and shows a tendency to micromanagement.

This part of the DC certainly gives ample justification for future dirigiste policymakers to involve the EU in the minutiae of social policy.

\section{Conclusions}

Two are the problems that plague the current institutions of the European Union. One is the effect of overlapping jurisdictions, resulting from layers and layers of agreements reached with a heavy emphasis on balancing. The second is a tendency of dirigisme and excessive faith in government intervention and policy coordination that also manifests itself in pompous and empty rhetoric.

The DC is trying to solve the first problem. The glass is half empty and half full The second problem, that we feel is probably more important, has to do with "culture" and visions about the role of government. In this respect the DC adds to the problems.

These views should not be taken as saying that the European integration project is intrinsically wrong. On the contrary there are many benefits form internalizing externalities and economies of scale that can be gained with a super national structure. In fact those areas where the two problems have been avoided have been a success for Europe. We offer two examples. One is the European Central Bank (ECB) and the common monetary policy. Here institutional complexity and turf war have been avoided ${ }^{14}$ : the ECB is a truly independent institution, and there is no confusion about who does what. The traditional European verbosity has also largely been avoided: rather than listing many objectives, from full employment to exchange rate stability and growth, the ECB has a clear objective of price stability (intelligently interpreted by the ECB as some form of inflation targeting). The result has been a success.

The second example is single market and competition policy. As Olivier Blanchard explains in this issue, anytime in this area the EU has managed to take a pro-market attitude, dismantling government subsidies and impediments to internal trade, it has had a beneficial effect. But, again, no institutional engineering has been able to prevent France and Germany from protecting their farmers, at the expense of the farmers of developing countries - all this, of course, accompanied by a heavy barrage of third world rhetoric.

${ }^{14}$ One exception is a turf war between the ECB and national Central Banks on issues of banking supervisions. 


\section{REFERENCES}

Alesina, A., I. Angeloni and L. Schuknecht (2002). What does the European Union do? NBER Working paper.

Alesina, A., and G. Tabellini (2004). Bureaucrats or politicians?” NBER Working Paper

Alesina, A., and R. Wacziarg (1998). Is Europe going too far? Carnegie Rochester Conference, Journal of Monetary Economics.

Baldwin R. and M. Wigdren (2003) Decision Making and the Constitutional Treaty: Wills the IGC discard Giscard? unpublished

Berglof, E., B. Eichengreen, G. Roland, G. Tabellini, and C. Wyplosz (2003). Built to last: A political architecture for Europe. CEPR, London.

Dewatripont M. I. Jewitt and J. Tirole (1999a) "The economics of career concerns part I" Review of Economic Studies, 66 183- 198

Dewatripont M. I I. Jewitt and J. Tirole (1999b) “The Economics of career concerns part II" Review of Economic Studies 66, $199-217$

Devuyst, Youri (2003): “The European Union at the Crossroads”, P.I.E. Peter Lang, Brussels

Evert, S. (2001). Unilateral America, lightweight Europe? CER Working Paper.

Evert, S. (2002). Shaping a credible EU foreign policy. Unpublished manuscript.

Evert, S., and D. Keohane (2003). The European Convention and EU foreign policy: Learning from failure. Survival, 167-86.

Gali J. and R. Perotti (2003) Fiscal Policy and Monetary Integration in Europe Economic Policy, forthcoming

Gordon P. (1997) Europe's uncommon foreign policy International Security 74-100

Heyman P. (2001) Dealing with terrorism International Security, 24-38

Holbrooke, R. (1999). How to end a war. Random House.

Kagan, R. (2002). Power and weakness. Policy Review, n. 113.

Keohane, D. (2003). The way forward for European defense. CER Bulletin.

Klau, T. (2003). France and Germany: A remarriage of convenience. The Brookings Institution.

Nutall S. (1992) European Political Cooperation Oxford University Press, Oxford UK

Posen B (2003) Command of the Commons The military foundations of US hegemony International Security 5-46. 
Schake, K. (2002). Constructive duplication: Reducing EU reliance on U.S. military assets. CER Working Paper.

Siendentop, L. (2000). Democracy in Europe. 